\title{
X ve Y Kuşağı: Hemşirelerde Meslek Dayanışması İle İş Doyumu Arasındaki İlişki
}

\author{
$X$ and Y Generation: The Relationship Between Nurses 'Professional Solidarity and \\ Job Satisfaction
}

\author{
Fatma KARASU, ${ }^{\text {iD }}$ Rukuye AYLAZ ${ }^{\text {b, }}{ }^{\text {Semih DADÜK }}{ }^{\text {iD }}$
}

\begin{abstract}
ÖZET Amaç: $\mathrm{Bu}$ araştırma, $\mathrm{X}$ ve $\mathrm{Y}$ kuşağındaki hemşirelerin meslek dayanışmasıı ile iş doyumu arasındaki ilişkisini belirlemek amacıyla yapılmıştır. Gereç ve Yöntem: Kesitsel nitelikteki araştırmanın evrenini devlet hastanesinde çalışan hemşireler oluşturmuş, örneklem seçimine gidilmeyerek evrenin tamamı örnekleme dahil edilmiş ve 01.02.2017-01.03.2017 tarihleri arasında çalışmayı kabul eden toplamda 145 hemşireye ulaşılmıştır. Veri toplama formunda, hemşirelerin sosyo-demografik özellikleri, Hemşirelerde Meslektaş Dayanışması Ölçeği ve Minnesota İş Doyumu Ölçeği yer almaktadır. Araştırmanın yapılacağı kurumdan, hemşirelerin sözel ve yazılı onamları alınmıştır. Veriler SPSS 18.0 programı ile değerlendirilmiş ve analizler sayı, yüzdelik ve ortalama, Cronbach-Alpha analizi, independent student t, Pearson's korelasyon testi uygulanmıştır. Tüm analizler için yanılma düzeyi 0.05 olarak belirlenmiştir. Bulgular: $Y$ kuşağı hemşirelerin, meslek dayanışma ölçeği toplam puan ortalamaları X kuşağına göre daha yüksek bulunmuş ancak $X$ ve $Y$ kuşağı arasında meslek dayanışma açısından istatistiksel olarak önemli bir fark saptanmamıştır $(\mathrm{p}>0.05)$. $\mathrm{X}$ kuşağ 1 hemşirelerin iş doyumu ölçeği puan ortalaması $\mathrm{Y}$ kuşağı hemşirelerden daha yüksek bulunmuş ve $\mathrm{X}$ ve $\mathrm{Y}$ kuşağı arasında iş doyumu açısından istatistiksel olarak önemli bir fark saptanmıştır $(\mathrm{p}<0.05)$. Sonuç: Araştırmaya katılan $Y$ kuşağı hemşirelerin meslek dayanışma ölçeği ortalamasının $\mathrm{X}$ kuşağından; $\mathrm{X}$ kuşağı hemşirelerin iş doyumu ölçeği puan ortalaması $\mathrm{Y}$ kuşağından daha yüksek bulunmuştur. Bu çalışmada, hemşireler arasında meslek dayanışması artıkça iş doyumunun da artığı saptanmıştır. Çalışan hemşirelerin meslek dayanışmalarını ve iş doyumunu artırılabilmek için kuşak farklılıkları da göz önünde bulundurulmalıdır.
\end{abstract}

Anahtar Kelime: Hemşirelik; X ve Y kuşağı; Kuşaklararası.

\begin{abstract}
Aim: This study was conducted to determine the relationship between professional solidarity and job satisfaction of nurses in the X and Y generation. Materials and Methods: Nurses working in the Kilis State Hospital constituted the universe of the cross-sectional study. All of the universe was included in the sampling without selecting the sample and 145 nurses who accepted to work between 01.02.2017 - 01.03.2017 were reached. In the data collection form, socio-demographic characteristics of the nurses, the Coworker's Solidarity Scale in Nurses and the Minnesota Job Satisfaction Scale are included. The verbal and written approvals of the nurses have been obtained from the institution to be conducted. The data were evaluated with SPSS 18.0 program and the analyzes were performed by number, percentage and mean, Crombach Alpha analysis, independent student t, Pearson's correlation test. For all analyzes the level of error was set at 0.05 . Results: Total point average of occupational solidarity scale of $\mathrm{Y}$ generation nurses was found to be higher than that of $\mathrm{X}$ axis, but there was not statistically significant difference in terms of occupational solidarity of $X$ and $Y$ generation $(p>0.05)$. The job satisfaction scale score of the $\mathrm{X}$ generation nurses was found to be higher than the $\mathrm{Y}$ generation nurses and a statistically significant difference was found between the $\mathrm{X}$ and $\mathrm{Y}$ generation job satisfactions $(\mathrm{p}<0.05)$. Conclusion: From the $\mathrm{X}$ of the average of the occupational solidarity scale of the $\mathrm{Y}$ generation nurses participating in the survey; The score of the job satisfaction scale of the $\mathrm{X}$ generation nurses was found to be higher than the $\mathrm{Y}$ curve. In this study, occupational solidarity among nurses was found to increase. Occupational solidarity of working nurses and job satisfaction should be considered in generation differences.
\end{abstract}

KeyWords: Nursing; X and Y generation; Intergenerational.

\section{Giriş}

Kuşak kavramı; yaklaşık olarak 25-30 yıllık yaş kümelerini oluşturan bireyler öbeği olarak tanımlanmakta olup, nesil ve jenerasyon keli- meleri ile de ifade edilebilmektedir. Türk Dil Kurumu'nun felsefe terimleri sözlüğünde; aşağ 1 yukarı aynı yıllarda doğmuş olup, aynı çağın

Geliş Tarihi/Received: 09-03-2017 / Kabul Tarihi/Accepted:19-09-2017

${ }^{a}$ Kilis 7 Aralık Üniversitesi/ Sağllk Yüksekokulu/Hemşirelik Bölümü//Öğretim Görevlisi

Adres: Kilis,Tel: 054174160 33e-mail: fatma.gecici@ hotmail.com; ORCID ID: 0000-0002-1979-781X

b İnönü Üniversitesi/Sağlık Bilimler Fakültesi/Öğretim Üyesi,Adres: Malatya, e-mail:

rukuye.aylaz@inonu.edu.tr; ORCID ID: 0000-0002-7347-0981

${ }^{\mathrm{c}}$ Kilis 7 Aralık Üniversitesi/ Sağlık Yüksekokulu/Hemşirelik Bölümü Öğrencisi,

16. Ulusal Hemșirelik Öğrenci Kongresine Gönderilmiștir.

Sorumlu yazar /Correspondence:Fatma Karasu, fatma.gecici@hotmail.com 
koşullarını, dolayısıyla birbirine benzer sıkıntıları, yazgıları yaşamış, benzer ödevlerle yükümlü olmuş kişiler topluluğu olarak tanımlamaktadır. ${ }^{1,2}$.

Literatürde günümüzde beş kuşağın varlığından söz edilmektedir: Sessiz/Savaş, Büyük Bebek Patlamas1, X, Y/Milenyum Kuşağı'dır. Sessiz Kuşak/Savaş Kuşağı: 19271945 yılları arasında doğanlardan oluşur, babaannelerimiz ve dedelerimizin kuşaklarıdır, uyumlu bir kuşak olup Türkiye'nin \%7'sini oluştururlar. Büyük Bebek Patlaması Kuşağl: 1946-1964 yılları arasında doğanlardan oluşur, kuralcı bir kuşak olup Türkiye'nin \%19'unu oluştururlar. X Kuşăgı: 1965-1979 yılları arasında doğanlardan oluşur, rekabetçi bir kuşak olup Türkiye'nin \%22'sini oluştururlar. $Y$ Kuşă̆ı: 1980-1999 yılları arasında doğanlardan oluşur, yaratıcı bir kuşak olup Türkiye'nin \%35'ini oluştururlar. Önümüzdeki 6 yıl içerisinde Y kuşağından \%50'ye yakın bir büyüme beklenmektedir. Z Kuşă̆g: 2000'den sonra doğan kristal çocuklardır, derin duygusallığ içeren bir kuşak olup, Türkiye'nin \%17'sini oluştururlar. Yaklaşık 5-10 yıl gibi kısa bir süre sonra da "Z Kuşağı" çalışma yaşamına katılmış olacaktır. ${ }^{3-5}$

$\mathrm{X}$ Kuşağı; çok stresli işlerden uzak durmaya çalışan, işi sadeleştiren ve yaşamak için yaptığ 1 işten keyif alan kuşaktır. X kuşağ1 üyeleri değişen dünya koşullarına yetişebilmek için büyük bir çaba harcamaktadırlar. İş yaşamında güvenlik ve maaş gibi unsurları ön planda tutmaktadırlar. ${ }^{6}$ Yapılan bir çalışmada; $\mathrm{X}$ Kuşağ ${ }_{1}$ hemşirelerinin işe karşı "uzun vadeli bağlılık" göstermediği ve "çalışma ortamından hoşlanmazsa kurumdan ayrılacağı" belirtilmektedir. ${ }^{7} \quad \mathrm{X}$ Kuşağı hemşirelerinin hayat sloganları "güç"tür. Bu kuşak hemşireleri kendilerini zorlu, iyimser ve kendine güvenen bireyler olarak tanımlamakta ve kurumdan daha çok yöneticiye sadakat gösterdiklerini belirtmektedirler. ${ }^{8}$.

Y kuşağında yer alan kişiler; özgürlüklerine düşkün, teknoloji tutkunu ve teknoloji kullanımını iyi bilen bir kuşak olarak tanımlanırlar ve işyerinde toplumun bir parçası olduklarını hissetmek istemektedirler. Örgütün stratejilerini dinlemek ve anlamak için gerçek bir çaba sarf etmektedirler ve örgütün vizyonu ile ilgili kritik bir noktada olmak ve örgütün ilerlemesi için yapılan yenilik çalışmalarının içinde olmayı seçmektedirler. ${ }^{6}$ Y Kuşağı hemşireleri, işte takımlar halinde çalışmayı tercih eder ve işlerinin anlamlı olmasını, büyük bir amaca katkıda bulunmasinı isterler. Eğlenceli bir çevre, gelişmek için firsatlar, iş projelerinde çeşitlilik, yeni beceriler öğrenme şansı ve esnek çalışma saatleri iş ortamında olması gereken en önemli niteliklerdir. ${ }^{9} \mathrm{Bu}$ kuşak hemşireleri, iş ve özel hayat arasında denge olmasını, işbirlikçi çalışmayı tercih ederlerdir. ${ }^{5,10}$

Meslektaş dayanışması, meslektaşların birbirlerine olan desteği ve mesleki anlamda bilgi, teknik ve beceri paylaşımı olarak tanımlanmaktadır. ${ }^{11} \quad$ Hemşireler, sıklıkla çalışma ortamlarında desteğe ihtiyaçları olduğunu önemle belirtirler. $\mathrm{Bu}$ desteğin en basta yönetim ve meslektaşlar tarafindan olabileceği vurgulanmaktadır. Destek aldığını hisseden bir hemşire, kendini güçlü ve yeterli (uzman) hisseder ve kendi tanıları üzerine daha çok güvenli olurlar. ${ }^{12}$ Çalışan hemşirenin iş çevresinde desteklenmesi, hastanın memnuniyetini artırmakta, kurumun memnuniyet ve işte kalma sonuçlarını da olumlu yönde etkilemektedir. ${ }^{13}$

İş doyumu yüksek olan bireylerin fizik ve ruh sağlıkları iyi, psikosomatik hastalıkları oldukça azdır ve iş arkadaşlarıyla yardımlaşma, kişisel güven, uyum ve iş birliği yüksek düzeydedir. Kaygı ile kaygının beraberinde getireceği rahatsızlıklar azdır. Bireyler yeni görevleri hızla öğrenebilmektedir. Ayrıca iş kazalar1 oldukça düşüktür. Kurum içindeki iş doyumunun yüksek olması, iş görenlerin başka iş arama eğilimlerini de azaltmaktadır. ${ }^{14}$ Öte yandan iş doyumsuzluğu, işe devamsızlık, kayıtsızlık, olumsuzluk, işi yavaşlatma, işten ayrılma ve benzeri gibi hizmeti olumsuz yönde etkileyen sonuçlara yol açabilmektedir. ${ }^{15}$

Hastanelerde iş gücünün en büyük parçasını hemşireler oluşturmaktadır ve hastanedeki iş çevresinin, hemşirelerin memnun olmalarını ve işe devam etmelerini etkileyen önemli bir faktör olduğu bilinmektedir. ${ }^{16}$ Hemşirelerde meslektaş dayanışmasının iş doyumunu pozitif yönde etkilediği saptanmıştır. ${ }^{14}$ Ülkemizde hemşirelerin iş doyumu üzerine yapılan çalışmalarda, hemşirelerin genel iş doyum düzeyinin ortanın biraz üzerinde olduğu belirlenmiştir. . $^{17,18}$

Literatürde iş doyumu yükseldikçe meslektaşların birbirine yardım etme davranışlarının da yükseldiği; bazı çalışmalarda da, iş yerinde meslektaşlardan, yöneticiden ve süpervizörden alınan desteğin, hemşirelerin iş doyumlarını olumlu yönde etkilediği; çalışma arkadaşları ile olumlu ilişkiler içinde olan 
çalışanların, iş doyumu düzeylerinin daha yüksek olduğu, aksine çalışma arkadaşları ile olumsuz ilişkiler içinde olan hemşirelerin ise iş doyumlarının daha düşük olduğu bulunmuştur. ${ }^{19-22}$ Hastanelerde iş gücünün en büyük parçasını $X$ ve $Y$ kuşağı hemşireler oluşturmaktadır. $\mathrm{Bu}$ çalışma $\mathrm{X}$ ve $\mathrm{Y}$ kuşağındaki hemşirelerin meslek dayanışması ile iş doyumu arasındaki ilişkisini belirlemek amacıyla planlanmıştır.

\section{Gerec ve Yöntem}

\section{Araştırmanın Evren ve Örneklemi}

Kesitsel nitelikteki araştırmanın evrenini Kilis Devlet Hastanesi'nde çalışan hemşireler oluşturmuş (201), örneklem seçimine gidilmeyerek evrenin tamamı örnekleme dahil edilmiş ve toplamda çalışmayı kabul eden 145 hemşireye ulaşılmıştır.

\section{Veri Toplama Araçları}

Veriler 01.02.2017-01.03.2017 tarihleri arasında toplanmıştır. Veri toplama formu, hemşirelerin sosyo-demografik ve çalışma durumu ile ilgili özelliklerini içeren toplam 13 sorudan oluşmaktadır.

Hemşirelerde Meslektaş Dayanışması Ölçeği (HMDÖ): Hemşirelerin kendi aralarındaki dayanışmayı ölçmek amacıyla kullanılan HMDÖ, Uslusoy (2010) tarafindan geliştirilmiştir. ${ }^{23}$ Hemşirelerde Meslektaş Dayanışması Ölçeği, beşli likert tipi bir ölçek olup, 23 sorudan oluşmaktadır. Ölçeğin "duygusal dayanışma", "akademik dayanışma" ve "dayanışma ile ilgili olumsuz düşünceler" olmak üzere üç alt boyutu vardır. "duygusal dayanışma" alt boyutunda, meslektaşların birbirlerine karşı göstermiş oldukları duygusal yönde arkadaşlık ilişkileri (Madde $5,7,8,11,12,14,15,16,18)$; "akademik dayanışma" alt boyutunda, mesleki anlamda gösterilen dayanışma davranışları (Madde $1,4,9,10,13,17,20,21,22)$ ve "dayanışma ile ilgili olumsuz düşünceler" alt boyutunda ise dayanışma davranışına yönelik olumsuz ifadelerin (Madde 2,3,6,19,23) yer aldığ1 maddeler bulunmaktadır. 2, 3, 6, 19 ve 23 . maddeler tersinden puanlanmıştır. Ölçekten alınan puan artıkça hemşirelerin meslektaşları ile dayanışma gösterme düzeyleri de artmaktadır. Ölçekten alınabilecek en düşük puan 23 , en yüksek puan ise $115^{\prime}$ dir. Ölçeğin Cronbach alfa katsayis1 0.80 olup $^{23}$, bu çalışmadaki Cronbach alfa katsayısı 0.844 olarak hesaplanmıştır.
Minnesota İ̧s Doyumu Ölçeği (MİDÖ): İş doyum düzeyini belirlemek amaciyla, Dawis, Weis, England ve Lofquist tarafindan geliştirilmiş olup (24), geçerlik-güvenirlik Türkçe uyarlaması Baycan (1985) tarafindan yapılmıştır. Minnesota iş doyum ölçeği, içsel ve dışsal doyum faktörlerini ortaya çıkarıcı özelliklere sahip, 20 maddeden oluşan, beşli likert tipi bir ölçme aracıdır. Ölçek puanlamasında, "hiç memnun değilim" 1 puan, "memnun değilim" 2 puan, "kararsızım" 3 puan, "memnunum" 4 puan, "çok memnunum" 5 puan olarak değerlendirilmektedir. Ölçek içsel doyum, dışsal doyum ve genel doyum puanlarını verir. Ölçekten alınabilecek en yüksek puan 100, en düşük puan 20 'dir. Puanların 25 altında olması düşük iş doyumu, 26-74 arasında olması normal iş doyumu, $75^{\prime}$ in üzerinde olması yüksek iş doyumunu ifade etmektedir. ${ }^{25}$ Ölçeğin Cronbach alfa katsayısı bu çalışma için 0.923 olarak he-saplanmıştır.

\section{Araștırmanın Etik Yönü}

Kilis Kamu Hastaneler Birliği Genel Sekreterliğinden gerekli izinler alındıktan sonra yapılmıştır. Katılımcılara çalışmaya katılma ya da katılmama veya istediği zaman çalışmayı bırakma hakkına sahip oldukları, bilgi vermeyi reddetme ve çalışmaya ilişkin aydınlatılmaya hakları olduğuna dair bilgi vermiş ve bilgilendirilmiş onamları alınmıştır. Çalışmaya katılmayı kabul eden bireylere kendilerinden alınan bilgilerin yalnızca anketi uygulayan kişi tarafindan değerlendirileceği, başka birisi tarafından incelenmeyeceği konusunda açıklama yapılmış ve sözlü, yazılı onamları alınmıştır.

\section{Verilerin Analizi ve Değerlendirilmesi}

Veriler SPSS 18.0 programında değerlendirilmiştir. Verilerin değerlendirilmesinde Kolmogorov-Smirnov testi sonucunda ölçek puanlarının normal dağılıma uyduğu belirlendi ve parametrik testler uyguland. Analizlerde sayı, yüzdelik ve ortalama, iç tutarlık analizi (Cronbach Alpha), independent student $t$, Pearson's korelasyon testi uygulanmıştır. Tüm analizler için yanılma düzeyi 0.05 olarak belirlenmiştir. "Bu değerden küçük ya da eşit "p" değerleri için istatistiksel olarak anlaml, büyük değerler için istatistiksel olarak anlamlı değildir yorumu yapılmıştır”. 


\begin{tabular}{|c|c|c|c|c|c|c|c|}
\hline \multirow[b]{2}{*}{ Değişkenler } & & \multicolumn{2}{|c|}{ X kuşağ } & \multicolumn{2}{|c|}{ Y kuşağ } & \multicolumn{2}{|c|}{ Toplam } \\
\hline & & $\mathrm{N}$ & $\%$ & $\mathrm{~N}$ & $\%$ & $\mathrm{~N}$ & $\%$ \\
\hline \multirow{2}{*}{ Cinsiyet } & Kadın & 22 & 81.5 & 83 & 70.3 & 105 & 72.4 \\
\hline & Erkek & 5 & 18.5 & 35 & 29.7 & 40 & 27.6 \\
\hline \multirow{4}{*}{ Eğitim Durumu } & Sağlık meslek lisesi & 4 & 14.8 & 22 & 18.6 & 26 & 17.9 \\
\hline & Ön Lisans & 18 & 66.7 & 21 & 17.8 & 39 & 26.9 \\
\hline & Lisans & 5 & 18.5 & 72 & 61.0 & 77 & 53.1 \\
\hline & Yüksek lisans & & & 3 & 2.5 & 3 & 2.1 \\
\hline \multirow{2}{*}{ Medeni Hali } & Bekar & 6 & 22.2 & 71 & 60.2 & 77 & 53.1 \\
\hline & Evli & 21 & 77.8 & 47 & 39.8 & 68 & 46.9 \\
\hline \multirow{2}{*}{ Aile Tipi } & Çekirdek & 20 & 74.1 & 96 & 81.4 & 116 & 80.0 \\
\hline & Geniş & 7 & 25.9 & 22 & 18.6 & 29 & 20.0 \\
\hline \multirow{3}{*}{ Çocuk Sayısı } & Çocuğu yok & 1 & 3.7 & 93 & 78.8 & 94 & 64.8 \\
\hline & $1-2$ aras 1 & 18 & 66.7 & 23 & 19.5 & 41 & 28.3 \\
\hline & 3 ve üzeri & 8 & 29.6 & 2 & 1.7 & 10 & 6.9 \\
\hline \multirow{3}{*}{$\begin{array}{l}\text { En Uzun Yaşanılan } \\
\text { Yer }\end{array}$} & Köy & 2 & 7.4 & 9 & 7.6 & 11 & 7.6 \\
\hline & Kasaba & 5 & 18.5 & 6 & 5.1 & 11 & 7.6 \\
\hline & Şehir & 20 & 74.1 & 103 & 87.3 & 123 & 84.8 \\
\hline \multirow{3}{*}{ Kardeş Sayısı } & Kardeşi yok & & & 3 & 2.5 & 3 & 2.1 \\
\hline & $1-2$ aras & 2 & 11.1 & 39 & 23.1 & 42 & 29.0 \\
\hline & 3 ve üzeri & 24 & 89.9 & 76 & 64.4 & 100 & 68.9 \\
\hline \multirow{4}{*}{$\begin{array}{l}\text { Kiminle } \\
\text { Yaşıyorsunuz }\end{array}$} & Ailemle (anne, baba, kardeş v.s) & 2 & 7.4 & 35 & 29.7 & 37 & 25.5 \\
\hline & Eşim ve çocuklarımla & 18 & 66.7 & 35 & 29.7 & 53 & 36.6 \\
\hline & Arkadaşımla & & & 9 & 7.6 & 9 & 6.2 \\
\hline & Yalnız & 7 & 25.9 & 39 & 33.1 & 46 & 31.7 \\
\hline \multirow{6}{*}{ Anne Eğitimi } & Okuryazar değil & 3 & 11.1 & 17 & 14.4 & 20 & 13.8 \\
\hline & Okuryazar & 7 & 25.9 & 12 & 10.2 & 19 & 13.1 \\
\hline & İlkokul & 11 & 40.7 & 48 & 40.7 & 59 & 40.7 \\
\hline & Ortaokul & 4 & 14.8 & 17 & 14.4 & 21 & 14.5 \\
\hline & Lise & & & 19 & 16.1 & 19 & 13.1 \\
\hline & Üniversite ve üzeri & 2 & 7.4 & 5 & 4.2 & 7 & 4.8 \\
\hline \multirow[t]{6}{*}{ Baba Eğitimi } & Okuryazar değil & 2 & 7.4 & 2 & 1.7 & 4 & 2.8 \\
\hline & Okuryazar & 3 & 11.1 & 6 & 5.1 & 9 & 6.2 \\
\hline & İlkokul & 15 & 55.6 & 41 & 34.7 & 56 & 38.6 \\
\hline & Ortaokul & 1 & 3.7 & 25 & 21.2 & 26 & 17.9 \\
\hline & Lise & 3 & 11.1 & 31 & 26.3 & 34 & 23.5 \\
\hline & Üniversite ve üzeri & 3 & 11.1 & 13 & 11.0 & 16 & 11.0 \\
\hline \multirow[t]{2}{*}{ Çalışma Yılı } & 5 yildan az & & & 83 & 70.3 & 83 & 57.2 \\
\hline & 5 yll ve üzeri & 27 & 100.0 & 35 & 29.7 & 62 & 42.8 \\
\hline Şuan Çalışılan & Yönetici Hemşire & 1 & 3.7 & & & 1 & 0.7 \\
\hline \multirow[t]{4}{*}{ Pozisyon } & Eğitim Hemşiresi & & & 2 & 1.7 & 2 & 1.4 \\
\hline & Yatak Baş1/Servis Hemşiresi & 19 & 70.4 & 111 & 94.1 & 130 & 89.7 \\
\hline & Ameliyathane Hemşiresi & 3 & 11.1 & 2 & 1.7 & 5 & 3.4 \\
\hline & Servis sorumlu Hemşiresi & 4 & 14.8 & 3 & 2.5 & 7 & 4.8 \\
\hline \multirow{2}{*}{$\begin{array}{l}\text { Şuan Çalışılan } \\
\text { Ünite Seçimi } \\
\end{array}$} & Kendi isteğimle seçtim & 14 & 51.9 & 70 & 59.3 & 84 & 57.9 \\
\hline & Hastane yönetiminin seçimi & 13 & 48.1 & 48 & 40.7 & 61 & 42.1 \\
\hline \multirow{3}{*}{$\begin{array}{l}\text { Şuan Çalışılan } \\
\text { Pozisyon Yılı }\end{array}$} & Bir yıldan az & & & 1 & 0.8 & 59 & 40.7 \\
\hline & $1-5$ y1l aras 1 & 18 & 66.3 & 100 & 84.9 & 60 & 41.4 \\
\hline & 5 yildan fazla & 9 & 33.3 & 17 & 14.3 & 26 & 15.9 \\
\hline
\end{tabular}

\section{Bulgular}

Hemşirelerin yaş ortalaması 28.93 \pm 7.55 ; \%81.4'ünün Y kuşağında; \%72.4'ünün kadın; $\% 53.1$ 'inin lisans mezunu; \%53.1'inini bekar; \%80.0'ının çekirdek aile; \%28.3'ünün 1-2 arasında çocuğu olduğu; \%84.8'inin en uzun olarak şehirde yaşadığı; \%68.9'unun 3 ve üzeri kardeşe sahip; \%36.6'sının eşi ve çocukları ile yaşadığı; \%40.7'sinin annesinin ve \%38.6'sının babasının ilkokul mezunu olduğu saptanmıştır. Hemşirelerin \%57.2'sinin 5 yıldan daha az bir süredir çalıştı̆̆1; \%89.7'sinin yatak başı/servis hemşiresi olarak çalıştığı; \%57.9'unun şuanda çalıştığ1 üniteyi kendi istekleriyle seçtiği; \%41.4'ünün şuan çalıştıkları ünitede 1-5 yıl arasında çalıştığı belirlenmiştir (Tablo 1). 
Tablo 2: Hemşirelerin meslek dayanışması ve iş doyumu ölçeği ortalamaları

\begin{tabular}{lccc}
\hline & $\mathrm{N}$ & Ort \pm SS & $\begin{array}{c}\text { Min.- Max. } \\
\text { Puan }\end{array}$ \\
\hline HMDÖ Alt Boyutları & & & $26-45$ \\
$\quad$ Duygusal Dayanışma & 145 & $39.22 \pm 4.60$ & $26-45$ \\
$\quad$ Akademik Dayanışma & 145 & $37.33 \pm 4.15$ & $5-25$ \\
$\quad$ Dayanışma İle İlgili Olumsuz Düşünceler & 145 & $18.08 \pm 4.59$ & $70-112$ \\
HMDÖ Toplam Puan & 145 & $94.64 \pm 10.19$ & $20-87$ \\
MİDÖ & 145 & $58.60 \pm 15.21$ & $\mathrm{n}(\%)$ \\
MİDÖ Puan Değerlendirilmesi & & $3(2,1)$ & $119(82,1)$ \\
$\quad$ Düşük iş doyumu (25 altında) & & $25(15,9)$ & \\
Normal iş doyumu (26-74 arasinda) & & & \\
$\quad$ Yüksek iş doyumunu (75'in üzerinde) & & & \\
\hline
\end{tabular}

Ort \pm SS: Ortalama ve standart sapma, HMDÖ: Hemşirelerde Meslektaş Dayanışması Ölçeği, MíDÖ:

Minnesota İş Doyumu Ölçeği, Min.- Max. : minimum ve maksimum puanları

Tablo 3: X ve Y kuşağı hemşirelerine göre meslek dayanışması ve iş doyumu ortalamaları karşılaştırılması

\begin{tabular}{lcccc}
\hline \multirow{2}{*}{ HMDÖ Alt Boyutları } & & $\mathrm{N}$ & Ort \pm SS & İstatistik* \\
\multirow{2}{*}{ Duygusal Dayanışma } & Kuşak & & & \\
& $\mathrm{X}$ & 27 & $39.85 \pm 3.43$ & $\mathrm{p}=0.162$ \\
\multirow{2}{*}{ Akademik Dayanı̧̧ma } & $\mathrm{Y}$ & 118 & $39.07 \pm 4.83$ & $\mathrm{t}=0.432$ \\
\hline \multirow{2}{*}{ Dayanışma İle İlgili Olumsuz Düşünceler } & $\mathrm{X}$ & 27 & $38.00 \pm 2.94$ & $\mathrm{p}=0.248$ \\
& $\mathrm{Y}$ & 118 & $37.18 \pm 4.38$ & $\mathrm{t}=1.168$ \\
\hline \multirow{2}{*}{ HMDÖ Toplam Puan } & $\mathrm{X}$ & 27 & $16.77 \pm 4.99$ & $\mathrm{p}=0.102$ \\
& $\mathrm{Y}$ & 118 & $18.38 \pm 4.46$ & $\mathrm{t}=-1.645$ \\
\hline \multirow{2}{*}{ MíDÖ } & $\mathrm{X}$ & 27 & $94.62 \pm 7.42$ & $\mathrm{p}=0.993$ \\
& $\mathrm{Y}$ & 118 & $95.44 \pm 10.75$ & $\mathrm{t}=-0.007$ \\
\hline
\end{tabular}

Ort \pm SS: Ortalama ve standart sapma, HMDÖ: Hemşirelerde Meslektaş Dayanışması Ölçeği, MIDÖ:

Minnesota İş Doyumu Ölçeği. * Independent Samples Testi kullanılmıştır.

Çalışmaya katılan hemşirelerin meslek dayanışma ölçeği toplam puan ortalamaları $94.64 \pm 10.19$, "duygusal dayanışma" alt boyutundan ald1kları ortalama puanın 39.22 \pm 4.60 , "akademik dayanışma" alt boyutundan aldıkları ortalama puanın $37.33 \pm 4.15$, "dayanışma ile ilgili olumsuz düşünceler" alt boyutundan aldıkları ortalama puanın $18.08 \pm 4.59$ olduğu belirlenmiştir. Hemşirelerin iş doyum ölçeği puan ortalamaları $58.60 \pm 15.21$ olduğu, $\% 80.5$ 'inin normal iş doyumuna sahip olduğu belirlenmiștir (Tablo 2).

Y kuşağ 1 hemşirelerin meslek dayanışma ölçeği toplam puan ortalamaları $\mathrm{X}$ kuşağına göre daha yüksek bulunmuş ancak $X$ ve $\mathrm{Y}$ kuşağ 1 arasında meslek dayanışma açısından istatistiksel olarak önemli bir fark saptanmamıştır ( $p>0.05)$. X kuşağı hemşirelerin "Duygusal dayanışma" ve "Akademik dayanışma" alt boyutunda aldıkları ortalama puanları Y kuşağı hemşirelerden daha yüksek saptanmıştır. Y kuşağı hemşirelerin "Dayanıșma ile ilgili olumsuz düşünceler" alt boyutunda aldıkları ortalama puanları X kuşağı hemşirelerden daha yüksek belirlenmiştir (Tablo 3).

$\mathrm{X}$ kuşağı hemşirelerin iş doyumu ölçeğ $\mathrm{i}$ puan ortalaması $\mathrm{Y}$ kuşağ 1 hemşirelerden daha yüksek bulunmuş ve $\mathrm{X}$ ve $\mathrm{Y}$ kuşağı iş doyumu açısından istatistiksel olarak önemli bir fark saptanmıştır $(\mathrm{p}<0.05)$ (Tablo 3).

$\mathrm{Bu}$ çalışmada, hemşirelerde meslek dayanışması ile iş doyumu arasında pozitif yönde ve orta düzeyde bir ilişki olduğu, meslek dayanışması artıkça iş doyumunun da artığı ya da iş doyumu artıkça meslek dayanışmasının da $\operatorname{artığ1~saptanmıştır~}(\mathrm{r}=0.367 ; \mathrm{p}<0.05)$ (Tablo 4). 
Tablo 4: Hemşirelerin meslek dayanışma ölçeği ile iş doyumu ölçeği arasındaki korelasyon dağılımı $(\mathrm{N}=145)$

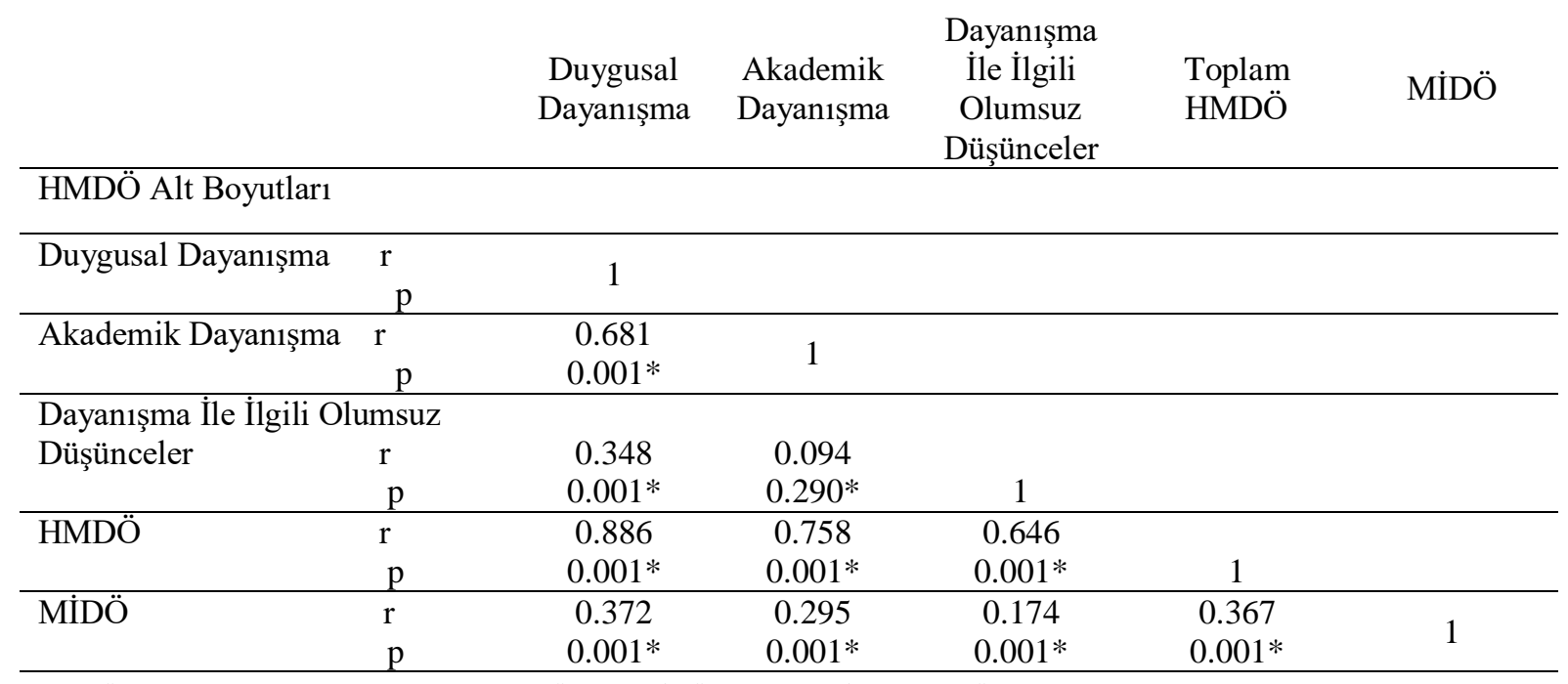

HMDÖ: Hemşirelerde Meslektaş Dayanışması Ölçeği, MiDÖ: Minnesota İş Doyumu Ölçeği.

*Korelasyon anlamlılık derecesi 0.05 'dir.

\section{Tartışma}

Çalışanların bağlılık ve tatmin noktasında yüksek düzeye ulaşabilmesi, çeşitli değişkenler aracılığı ile araştırma konusu olmuştur. Ancak giderek artan kuşak değişkeni kavramının önemi, $\mathrm{X}$ ve $\mathrm{Y}$ kuşaklarının aynı organizasyonda çalışmaya başlaması ile oluşmuştur. $\mathrm{Bu}$ iki kuşağın farklı özellikler yansıtması, iş yaşamı ve örgütsel bağlılık açısından da değişkenlik göstermektedir. ${ }^{26}$ İş yerinde nesiller arasındaki farklılıkları anlamak, farklı çalışan ihtiyaçlarını karşılamada yararlı bir ilk adımdır. 27

Sağlık çalışanları içerisinde hemşirelerin birbirlerini güven içerisinde desteklemeleri ve dayanışma içerisinde olmaları, kurumu istenmeyen davranışlardan koruyarak, çalışanların tükenmişliklerini azaltmakta, yetenek ve becerilerini geliștirmekte ve etkin bir koordinasyon kurarak kurumun verimliliğini artırmaktadır. $^{28,29}$ Hemşireler arasında gösterilmesi beklenen meslek dayanışması ve iş doyumları, hemşirelik bakımının etkinliğini artırmada önemli bir role sahiptir.

Çalıșmamızda, hemşirelerin HMDÖ’den aldıkları genel puan ortalaması $94.64 \pm 10.19$ olup \%50.2'sinin ortalamanın üzerinde, \%49.8'inin ortalamanın altında puan aldığ saptanmıştır. Hemşirelerin "duygusal dayanışma" alt boyutundan aldikları puan ortalaması “akademik dayanıșma" alt boyutundan aldıkları puan ortalamasından daha yüksek bulunmuştur (Tablo 2). Ölçekten alınabilecek en düşük puan 23, en yüksek puan ise 115 olduğundan, hemşirelerin HMDÖ'den aldıkları puan ortalaması meslek dayanışmasının var olduğunu göstermektedir.

$\mathrm{Bu}$ çalışmada, hemşirelerin iş doyum ölçeği puan ortalamasının $58.60 \pm 15.21$ olduğu belirlemiştir (Tablo 2). Tilev ve Beydağ' in Adana da yaptıkları çalışmada, hemşirelerin iş doyum düzey puan ortalamalarını 59.60 \pm 17.10 (18), Kundak ve ark.'nın Afyon'daki çalışmasında $61.91 \pm 16.08$ (30), Tambağ ve ark.'nın araştırmasında 64.24 \pm 11.00 (31), Süloğlu'nun yaptığ1 araştırmada $64.45 \pm 12.18$ olarak saptamıştır. ${ }^{32}$ Yapılan çalışmalarda elde edilen iş doyum değeri, bu çalışmadaki değer-den daha yüksek bulunmuştur. $\mathrm{Bu}$ da şuan ki Suriye savaşı, mülteci sayılarının artması, Kilis ilinin sınır bölgesinde yer alması nedeniyle artan iş yükünü akla getirmektedir.

Y kuşağ1 hemşirelerin HMDÖ ortalaması $\mathrm{X}$ kuşağına göre daha yüksek bulunmuş ancak $\mathrm{X}$ ve $\mathrm{Y}$ kuşağı meslek dayanışma açısından istatistiksel olarak önemli bir fark saptanmamıştır ( $\mathrm{p}>0.05)$. X kuşağı "duygusal dayanışma" ve "akademik dayanışma" alt boyutunda Y kuşağına göre daha yüksek ortalamaya sahiptir. Ancak Y kuşağı hemşirelerin “dayanışma ile ilgili olumsuz düşünceler" alt boyutunda aldıkları ortalama puan X kuşağı hemşirelerden daha yüksek olduğu belirlenmiştir (Tablo 3). Nkomo'nun yaptığı çalışmada genç yaştaki işçiler olan Y kuşağının $\mathrm{X}$ kuşağından daha yüksek olarak örgütsel bağliliğa sahip olduğunu bulmuştur. ${ }^{33}$ Khanolkar'ın yaptığg çalışmada, Y kuşağının kişisel özellikler yapısına uygun iş yerlerinde 
örgütsel bağlılıklarının daha yüksek olduğunu saptamıştır. ${ }^{34}$ Mahoney'in yaptığı çalışmada X ve Y kuşaklar arasında örgütsel bağlllık arasında farkl111k olduğunu saptanıştır. ${ }^{35}$. Koç ve ark.'nın yaptığı çalışmada X ve Y kuşaklar arasında örgütsel dayanışma bir fark saptamamıştır. ${ }^{36}$. Kian ve Yusoff'un yaptığı çalışmada sonucunda; Y kuşağının X kuşağına göre örgütsel bağl1lıklarının daha düşük olduğunu bulmuştur. ${ }^{37}$ Literatürde $\mathrm{X}$ kuşağ1 bireyleri, değişen dünya koşullarına yetişebilmek için büyük bir çaba harcamakla birlikte, toplumsal sorunlara duyarlı, mücadeleci, küresel düşünen, işlerine bağlı ancak bireycilliği ön planda tutan tedbirli ve garanticidirler. $\mathrm{X}$ kuşağı bireyleri takım çalışmasından çok bireysel olarak çalışmaya daha yatkındırlar ve tek başlarına çok iyi çalışırlar. Aynı zamanda özgürlüklerine düşkün ve vefalı değillerdir. $\mathrm{Y}$ kuşağı bireyler ise yenilikçi, kendine güvenen, ekip arkadaşlarına bağlı ve takım çalışmasına yatkın, kişisel ve mesleki gelişimde eğitim ve öğrenimin sürekliliğine inanan bir kuşak olarak nitelendirilmektedir. ${ }^{5,29,38,39} \mathrm{Y}$ kuşağ 1 bireyler iş yerinde ekip çalışması ve topluluk duygusu sergileyen ortamlar ararlar. Güçlü bir ekip kültürüne ve düzenli ekip toplantılarına dahil olmak isterler. ${ }^{40} \mathrm{X}$ ve $\mathrm{Y}$ kuşağ $\mathrm{g}$ bireyleri iş ahlaklarını farklı algılamaktadırlar. ${ }^{29}$ Duygusal dayanışma ya da bağlılık meslek-taşların birbirlerine göstermiş oldukları duygusal arkadaşlık ilişkilerini ve bireylerin istedikleri için işte ya da örgütte kaldığını göstermektedir. Gürbüz'ün (öğretmenler, dok-tor, hemşire, hazır gıda, veri hazırlama ve kontrol işleri, tekstil ve güvenlik hizmetleri çalışanları ile) yaptığı çalışmada, $X$ kuşağının duygusal bağl11ık düzeyinin Y kuşağına göre daha yüksek olduğu belirlenmiştir. ${ }^{41}$

$\mathrm{X}$ kuşağ 1 hemşirelerin iş doyum ölçek puan ortalaması $\mathrm{Y}$ kuşağı hemşirelerden daha yüksek bulunmuştur (Tablo 3). Kuşaklar arasında iş doyumu, X kuşağında daha yüksek saptanmıştır. Nkomo'nun yaptığı çalışmada X kuşağının Y kuşağından daha yüksek bir iş doyumuna sahip olduğunu saptamıştır. ${ }^{33}$ Kian ve Yusoff'un yaptığı çalışmada X kuşağının iş tatmini $Y$ kuşağından daha yüksek olarak bulmuştur. ${ }^{37}$ Gürbüz'ün yaptığı çalışmada, $X$ kuşağının iş tatmin düzeyinin Y kuşağına göre daha yüksek olduğu saptanmıştır. ${ }^{41} \mathrm{X}$ kuşağ1 çalışanları, iş yaşamında sadık, kanaat duyguları yüksek ve aynı işte uzun yılar çalışmış, iş yerlerine bağlı ancak özel yaşam dengesini korumaya özen gösteren, otoriteye saygıl1, saygın bir statüye sahip olma, başarıya yönelik ödüllendirme beklentileri olan bireyler olarak bilinirler. ${ }^{29,41,42}$. X kuşağı bireyleri kariyer gelişimine çok fazla odaklanmışlardır ve gelecekteki kariyer beklentilerini artırmak için mesleki becerilerini arttırma arzusuyla motive olmuşlardır. ${ }^{37}$. Koç ve ark.'nın yaptığı çalışmada $\mathrm{X}$ ve $\mathrm{Y}$ kuşaklar arasında iş doyumu açısından bir fark bulmamıştır. ${ }^{36}$. X kuşağ 1 bireyleri, çok stresli işlerden uzak durmaya çalışan, işi sadeleştiren ve yaşamak için yaptığ 1 işten keyif alan bir kuşaktır. Y kuşağı bireyleri genel olarak, bağımsızlığına düşkün, işe bağl1lığ1 düşük, iş değişikliğini doğal gören, esnek çalışmanın gerekliliğine inanan, eleştiriye kapalı, elde ettikleri gelirden çok sosyal yardımlar, esnek çalışma saatleri, yaptıklarının onaylanması, işleri ile kendilerini ifade etmek gibi faktörlerinde dahil olduğu bütünsel bir iş tatmini onlar için önemlidir. ${ }^{29,41,42} \mathrm{Bu}$ bilgiler 1şında, hemşirelerde $\mathrm{X}$ ve $\mathrm{Y}$ kuşağı özelliklerini taşımaktadırlar.

$\mathrm{Bu}$ çalışmada, hemşirelerde meslek dayanışması ile iş doyumu arasında pozitif yönde bir ilişki olduğu, meslek dayanışması artıkça iş doyumunun da artığ 1 saptanmıştır (Tablo 4). Koç ve ark.'nın yaptığı çalışmada iş tatmini ile örgütsel bağlılık arasında, istatistik açıdan pozitif yönde ve anlamlı bir ilişki tespit etmiştir $^{36}$ Sönmez'in yaptı̆̆ 1 araştırmada, çalışanların yaşlarının artmasıyla birlikte, iş tatmini ve örgütsel bağl1lık düzeylerinin artığını saptamıştır. Yaş arttıkça yapılan işten duyulan genel iş tatmini de artmaktadır ${ }^{43}$. Literatürde, hemşireler arasında oluşan desteğin iş doyumunu olumlu yönde etkilediğini ${ }^{20,44}$ iş doyumu artıkça meslektaşların birbirine yardım etme davranışlarının da $\operatorname{artığ} 1{ }^{19}$ çalışma arkadaşları ile olumlu ilişkiler içinde olan bireylerin iş doyumlarının daha yüksek olduğu saptanmıştır. ${ }^{15,21}$

\section{Sonuç}

Araştırmaya katılan hemşireler arasında meslek dayanışmasının olduğu ve duygusal dayanışmanın akademik dayanışmadan daha yüksek düzeyde olduğu belirlenmiştir. Hemşirelerden 119'u normal, 23 ise yüksek oranda iş doyumuna sahip olduğu saptanmıştır. Y kuşağı hemşirelerin HMDÖ ortalaması X kuşağına göre daha yüksek bulunmuştur. $X$ kuşağı "duygusal dayanışma" ve "akademik dayanışma" alt boyutunda Y kuşağına göre daha yüksek ortalamaya sahipken Y kuşağı hemşirelerin 
"dayanışma ile ilgili olumsuz düşünceler" alt boyutunda aldıkları ortalama puan X kuşağı hemşirelerden daha yüksek olduğu saptanmıştır. X kuşağı hemşirelerin iş doyumu ölçeği puan ortalaması Y kuşağı hemşirelerden daha yüksek bulunmuştur. Bu çalışmada, hemşireler arasında meslek dayanışması ile iş doyumu ilişkili bulunmuştur.

$\mathrm{Bu}$ bulgular doğrultusunda, hemşirelik eğitiminde ve hizmet içi eğitimlerle meslek dayanışmaların önemi için çalışmaların planlanması ve uygulanmasının iş doyumunu artırılabileceği ve bu planlamaları ve uygulamaları yaparken, kuşak farklılıkları ile bireylerin iş değerleri, davranış kalıplarının farklı olacağ̀ unutulmamalıdır. Kuşaklar aras1 farklılıkları ortaya koyan sınırlı sayıda çalışma vardır ve hatta hemşirelik alanında yok denecek kadar azdır. Hemşirelikte kuşaklar arası farkl11ıkları ortaya koymak için daha geniş örneklemli bilimsel araştırmalar yapılması önerilmektedir.

\section{Kaynaklar}

1. TDK, Büyük Türkçe Sözlük (http://www.tdk.gov.tr/index.php?option=c om_bts\&view=bts) Erişim Tarihi:14.12.2016

2. Sullivan SE, Forret ML, Carraher SM, Maiminero LA. "Using the kaleidescope career model to examine generational differences in work attitudes". Fairfield University Digital Commons, 2009;14(3):284-302.

3 . Exploring the needs of early career nurses and midwives in the workplace. https://www.hee.nhs.uk/sites/default/files/d ocuments/Mind\%20the\%20Gap\%20Report _o.pdf (Erişim tarihi: 21.08.217)

4. Applebaum D, Fowler S, Fiedler N, Osinubi $\mathrm{O}$, Robson M. The impact of environmental factors on nursing stress, job satisfaction, and turnover intention. JONA 2010;40(7/8):323-328.

5. Yılmaz K. Hemşireliği gelecekte nasıl bir nesil bekliyor? Acıbadem Hemşirelik edergisi 2013;62: 1-7. http://www.acibademhemsirelik.com/edergi/62/docs/makale2-62.pdf

6. Adıgüzel O, Batur Z, Ekşili N. "Kuşakların değişen yüzü ve y kuşağı ile ortaya çıkan yeni çalışma tarzı: mobil yakalılar". Süleyman Demirel Üniversitesi Sosyal Bilimler Enstitüsü Dergisi 2014;19:165-182.
7. Swearingen S. Nursing leadership characteristics: effect on nursing job satisfaction and retention of baby boomer and generation $\mathrm{x}$. University of Central Florida for the degree of Doctor of Philosophy, 2004.

8. Hu J, Herrick C, Hodgin K. Managing the multigenerational nursing team. The Health CareManager, 2004; 23(4):334-340.

9. Carver L, Candela L. Attaining organizational commitment across different generations of nurses. Journal of Nursing Management, 2008; 16: 984- 991.

10. Duchscher JEB, Cowin L. Multigenerational nurses in the workplace. JONA 2004;34(11):493-501.

11. Çoban AE. Psikolojik danışmanlar için meslektaş dayanışması. Mersin Üniversitesi Eğitim Fakültesi Dergisi 2005;1(1):167-174.

12. Hagbaghery MA, Salsali M, Ahmadi F. A qualitative study of _ranian nurses' understanding and experiences of professional power. Human Resoruces for Health 2004;2(9):1-14.

13. Lacey SR, Teasley SL, Henion JS, Cox KS, Bonura A, Brown J. Enhancing the work environment of staff nurses using targeted interventions of support. JONA 2008;38(7/8):336-340.

14. Çetinkaya Ulusoy E, Ecevit Alpar Ş. Hemşirelerde meslektaş dayanışması ve iş doyumu ile ilişkisi. F.N. Hemşirelik Dergi 2013;21(3): 154-163.

15. Serinkan C, Bardakçı A. Pamukkale Üniversitesi'ndeki akademik personelin iş doyumları ve tükenmişlik düzeylerine ilişkin bir araştırma. Sosyal Bilimler Dergisi 2009;21:115-132.

16. Latham CL, Hogan M, Ringl K. Nurses supporting nurses, creating a mentoring program foe staff nurses to improve to workforce environment. Nurs Admin 2008;32(1);27-39.

17. İntepeler SŞ, Güneş N, Bengü N, Yılmazmış F. Bir üniversite hastanesinde çalışan hemşirelerin iş doyumu ve kurumsal bağl1lıklarındaki değişim. Dokuz Eylül Üniversitesi Hemşirelik Yüksekokulu Elektronik Dergisi 2014;7(1):2-6.

18. Tilev $\mathrm{S}$, Beydağ KD. Hemşirelerin iş doyum düzeyi. Sağlık ve Hemşirelik Yönetim Dergisi 2014;3(1):140-147.

19. Atlaş SS. Çekmecelioğlu HG. İş tatmini, örgütsel bağl1lık ve örgütsel vatandaşl1k 
davranışının iş performansı üzerindeki etkileri: Bir araştırma. Öneri Dergisi 2007;7(28):47-57.

20. Wilkins K, Shields M. Employer-provided support services and job dissatisfacion in Canadian registered nurses. Nursing Research 2009;58(4):255-263.

21. Çam $\mathrm{O}$, Yıldırım $\mathrm{S}$. Hemşirelerde iş doyumu ve etkileyen faktörler. Türkiye Klinikleri J Nurs Sci 2010;2(1):64-70.

22. Dede M, Çınar S. Dahiliye yoğun bakım hemşirelerinin karşılaştıkları güçlükler ve iş doyumlarının belirlenmesi. Maltepe Üniversitesi Hemşirelik Bilim ve Sanatı Dergisi 2008;1(1):3-14.

23. Uslusoy E. Hemşirelerde Meslektaş Dayanışması Ölçeği' nin geliştirilmesi ve meslektaş dayanışmasının iş doyumu ile ilişkisi. Doktora Tezi, Marmara Üniversitesi Sağlık Bilimleri Enstitüsü, 2010, İstanbul.

24. Weiss DJ, Dawis RV, England GW, Lofquist LH. (1967). Manual of the minnesota satisfaction questionnaire. Minneapolis: MN: The University of Minnesota Press.

25. Baycan A. Farklı gruplarda çalışan kişilerde iş doyumunun bazı yönlerinin analizi. Yayınlanmamış Yüksek Lisans Tezi, Boğaziçi Üniversitesi, 1985, İstanbul.

26. Waal A, Linde P, Broekhuizen M. Do different generations look differently at high performance organizations?. Journal of Strategy and Management 2017; 10(1): 86-101.

27. Cennamo L, Gardner D. Generational differences in work values, outcomes and person-organisation values fit. Journal of Managerial Psychology 2008; 23(8): 891906. DOI 10.1108/02683940810904385

28. Aslan Ş. Örgütsel vatandaşlık davranışı ile örgütsel bağl1lık ve mesleğe bağl1lık arasındaki ilişkilerin araştırılması. Yönetim ve Ekonomi 2008;15(2):163-178.

29. Çetin Aydın G, Başol O. X ve Y kuşağı: çalışmanın anlamında bir değişme var mı? Electronic Journal of Vocational CollegesDecember/Aralık 2014;1-15.

30. Kundak Z, Üzel Taş H, Keleş A, Eğicioğlu H. Bir Üniversite Hastanesinde hemşirelik mesleğinde iş tatmini ve motivasyon. Kocatepe Tip Dergisi 2015;16: 1-10.

31. Tambağ H. Can R. Kahraman Y. Şahpolat M. Hemşirelerin çalışma ortamlarının iş doyumu üzerine etkisi. Bakırköy Tıp Dergisi 2015;11(4): 143- 149.

32. Süloğlu A. Diyaliz Merkezlerinde çalışan doktor ve hemşirelerde tükenmişlik sendromu. Aile Hekimliği Uzmanlık Tezi İstanbul, 2009.

33. Nkomo E. Motivation, Work Values, Organisational Commitment And Job Satisfaction: Age And Generational Cohort Effects. South Africa, September 2013.

http://wiredspace.wits.ac.za/bitstream/han dle/10539/13994/FINAL\%20FOR\%20PR INTING\%202.pdf?sequence $=2$

34. Khanolkar RS. "Influence of Employer Branding on Satisfaction and Commitment of Generation Y Employees", IOSR Journal of Business and Management (IOSR-JBM), e-ISSN: 2278-487X, pISSN: 2319-7668:2013;13-18.

35. Mahoney A. Commitment and Employee Development: Comparing Generations X and Y. http://scholarworks.sjsu.edu/etd theses

36. Koç M, Öztürk L, Yıldırım A. X ve $Y$ kuşağının iş tatmini ve örgütsel bağlıllı̆̆ üzerine bir araştırma. Research Journal of Business and Management- RJBM 2016;3(2). 173-183.

37. Kian TS, Yusoff WF. "Generation X and Y and their work motivation", Proceedings International Conference of Technology Management Business and Entrepreneurship, Malaysia 18-19 Dec: 2012: 396-408.

38. Karaaslan S. Kuşaklararası farklılıkları örgütler üzerinden anlamak: bir alan araştırması. Yüksek Lisans Tezi, Ankara Üniversitesi, Sosyal Bilimler Enstitüsü. 2014.

39. Ayhün SE. Kuşaklar arasındaki farklılıklar ve örgütsel yansimaları. Ekonomi ve Yönetim Araştırmaları Dergisi 2013; 2 (1): 93-112.

40. Jones K, Warrren A, Davies A. Mind the Gap: Exploring the needs of early career nurses and midwives in the workplace. Summary report from Birmingham and Solihull Local Education and Training Council Every Student Counts Project. Published May 2015.

41. Gürbüz S. Kuşak Farkl1lıkları: Mit mi, Gerçek mi? İş ve İnsan Dergisi, 2015; 2(1), 39-57. 
42. Demirkaya H, Akdemir A, Karaman E, Atan Ö. Kuşakların yönetim politikası beklentilerinin araştırılması. İşletme Araştırmaları Dergisi, 2015; 7(1): 186204.

43. Sönmez H. "Değişim Yaşanan Örgütlerde İş Tatmini İle Örgütsel Bağl1lık İlişkisi”, Yüksek Lisans Tezi, Ege Üniversitesi
Sosyal Bilimler Enstitüsü İşletme Anabilim Dalı Yönetim Bilimi ve Organizasyon Bilim Dalı İzmir. 2014.

44. Küçükyılmaz Ü, Gök Özer F, Taşçı KD. Devlet hastanesinde çalışan hemşirelerin iş doyum düzeylerinin belirlenmesi. Hemșirelik Forumu 2006; 37-46. 